\title{
Islamic Insurance: A Potential Niche Market of Indonesia
}

\author{
Jaenal Effendi
}

\begin{abstract}
Islamic insurance in Indonesia is potentially expected to grow along with the increase in Islamic financial market. Hence, this paper aims to develop strategy and policy recommendations for stakeholders of Islamic insurance industry in Indonesia. This article applied ANP approach by classifying it into three aspects, namely problem, solution, and strategy. Problem and solution aspects consist of four clusters including internal, customer, competition, as well as regulation. Also, strategy offered is the strategy to improve the quality of service, strategy to develop the relationship and synergy between the authorities and the Islamic Financial Institutions.
\end{abstract}

Keywords: Islamic insurance, niche market, analytical network process.

\begin{abstract}
Abstrak. Asuransi syariah di Indonesia berpotensi untuk terus berkembang seiring dengan pertumbuhan pasar keuangan syariah. Oleh karena itu, tulisan ini bertujuan untuk mengembangkan strategi dan rekomendasi kebijakan bagi seluruh pelaku kepentingan industri asuransi syariah di Indonesia. Tulisan ini menerapkan pendekatan ANP dengan mengklasifikasikannya menjadi tiga aspek, yaitu masalah, solusi dan strategi. Aspek masalah dan solusinya terdiri dari empat kelompok meliputi masalah dan solusi internal asuransi syariah, masalah dan solusi pelanggan, masalah dan solusi persaingan, serta masalah dan solusi regulasi. Selain itu, strategi yang ditawarkan adalah strategi untuk meningkatkan kualitas layanan, strategi untuk meningkatkan hubungan dan sinergi antara pihak berwajib dan lembaga keuangan syariah.
\end{abstract}

Kata kunci: asuransi syariah, ceruk pasar, analytical network process

\section{How to Cite:}

Effendi, J. (2018). Islamic Insurance: A Potential Niche Market of Indonesia Al-Iqtishad: Jurnal Ilmu Ekonomi Syariah (Journal of Islamic Economics). Vol. 10 (1): 207 - 230. doi: http//dx.doi. org/10.15408/aiq.v10i1.5330 


\section{Introduction}

Islamic insurance has proliferated in the industry of Islamic finance in the world. Rahman (2009) predicted that its development would continue to grow approximately $15-20 \%$ per year. Islamic insurance or takaful continues to grow and show its contribution in the insurance market of Indonesia as the largest Muslim country, which has a population of 254.9 million people (BPS 2015). This number is a huge potential market for Islamic insurance products. Table 1 shows the development of national Islamic insurance from 2014 to 2016 based on Association from Islamic Insurance Society in Indonesia or AASI.

Table 1. Development of Islamic Insurance for the last 5 years (in Billion IDR)

\begin{tabular}{lccccc}
\hline \multicolumn{1}{c}{ Indicator } & $\mathbf{2 0 1 4}^{*}$ & $\mathbf{2 0 1 5}^{*}$ & Growth (\%) & $\mathbf{2 0 1 6}^{*}$ & Growth (\%) \\
\hline Asset & 17,198 & 23,803 & 27.75 & 28,967 & 17.83 \\
Investment & 14,816 & 20,808 & 28.80 & 25,726 & 19.12 \\
Contribution & 2,085 & 2,497 & 16.50 & 2,753 & 9.30 \\
\hline
\end{tabular}

Source AASI (2016)

Table 1 shows that the number of the asset, investment, and contribution of Islamic insurance during 2014 to 2016 slowly increased through their growths slightly decreased. Also, its contribution or premium market share compared to its counterparts was only $5.79 \%$ and its penetration to the total national population was only $0.095 \%$ in 2016 (AASI, 2016). It indicates that Islamic insurance should penetrate more market by conducting more development strategy.

Sherif and Shaairi (2013) stated that the development of Islamic banks positively affects the demand for Islamic insurance or takaful in Malaysia. However, the development of Islamic insurance in Indonesia is quite low when compared to the growth of Islamic banking industry. It seen from the side of total asset of which the Islamic Commercial Bank (Bank Umum Syariah, BUS) and Islamic Business Unit (Unit Usaha Syariah, UUS) had a total asset of IDR 331,763 trillion per September 2016. Total asset of Islamic banking was much more than Islamic insurance that amounted to IDR 23,640 trillion (OJK 2016).

There is a high relationship between Islamic financial institution, particularly Islamic bank and insurance. Islamic bank should direct its customers, who conduct financing to the insurance company, which comply Sharia principles. Therefore, the Islamic bank is one of the potential biggest markets of Islamic insurance. The number of financing and third funds in 2011 to 2016 shown in Figure 1. 
Figure 1. Number of Financing and Deposit Funds in Islamic Banks

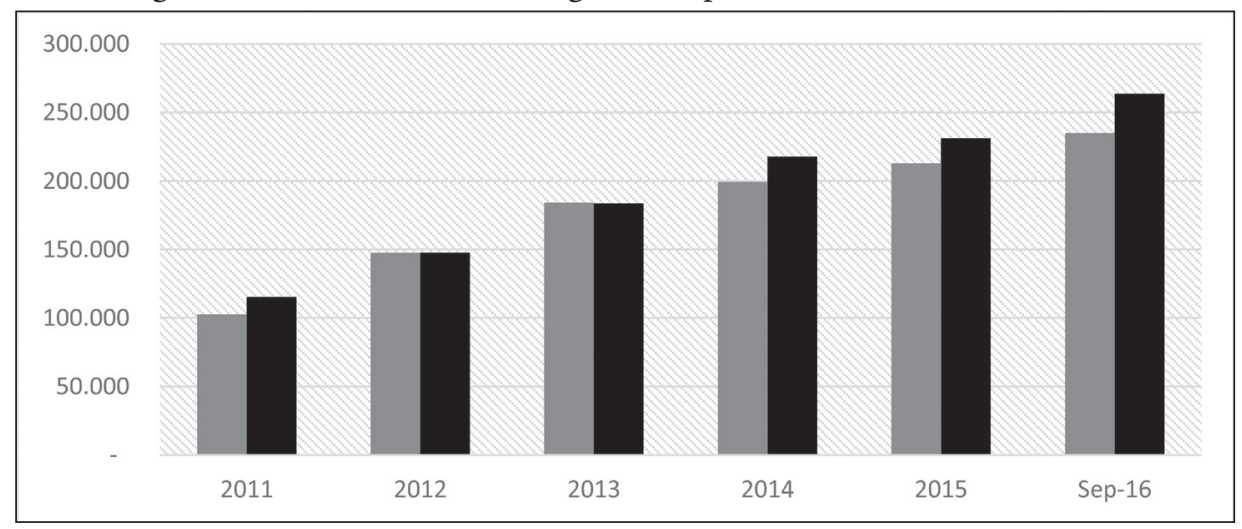

Based on Figure 1, the total financing of Islamic banks tended to increase in 5 years. Statement from AASI in 2017 stated that on average, contribution that has to be paid for financing contract was approximately $2 \%$ per total financing based on the In-depth interview with experts

Therefore, it would be amounted to IDR 4,700 billion. In fact, the total contribution of Islamic insurance was only IDR 2,753 billion. It implies that Islamic insurance has not optimized its potential market. Furthermore, it needs more strategies to increase its market. Hence, this study aims to develop strategies and policy recommendations for stakeholders, governments, and related institutions in the development of the Islamic insurance in Indonesia.

\section{Literature Review}

The rapid development of Islamic finance industry is correlated positively with the growth of Islamic insurance. Islamic insurance system has the concept of risk sharing rather than risk transfer like conventional insurance. The differences in conventional and Islamic insurance systems are explained by Soemitra (2014) in Table 2.

Islamic insurance schemes contain aspects of sharia values that are not shared by conventional insurance systems, namely the principles of fairness, transparency, and risk sharing. The principle of risk sharing owned by Islamic insurance will extend the protection of property or life for disadvantaged members. If Islamic insurance company has surplus of funds, then it can be used to pay zakat or distributed to assist the construction of public infrastructure projects, such as school construction, hospitals, and other matters that are permitted by Islamic 
law (Swartz and Coetzer, 2010). The other advantage is that Islamic insurance products cannot only be marketed to Muslim communities but non-Muslims as well. For instance, Shariah compliant market share in non-Muslim province areas such as East Nusa Tenggara and North Sulawesi is experiencing encouraging growth. In addition, Islamic insurance products have even attracted non-Muslim communities, despite obvious religious and cultural differences in Malaysia as a multi-racial country, (Swartz and Coetzer, 2010).

Table 2. The Differences between Islamic and Conventional Insurance

\begin{tabular}{lll}
\hline Aspect & Islamic Insurance & Conventional Insurance \\
\hline $\begin{array}{l}\text { The Existance of } \\
\text { Sharia Supervisory } \\
\text { Board (DPS) }\end{array}$ & Has DPS & Has no DPS \\
\hline Contract & - Tabarru contract among the members \\
& $\begin{array}{l}\text { Tijarah contract between the member } \\
\text { and insurance company }\end{array}$ & $\begin{array}{l}\text { Contract is similar to buying } \\
\text { and selling (ta-badduli) }\end{array}$ \\
$\begin{array}{l}\text { Investment } \\
\text { activities }\end{array}$ & $\begin{array}{l}\text { Free from riba and others activities that } \\
\text { violate sharia principles }\end{array}$ & $\begin{array}{l}\text { Not free from riba and } \\
\text { others activities that violate } \\
\text { sharia principles }\end{array}$ \\
$\begin{array}{l}\text { The ownership of } \\
\text { the funds }\end{array}$ & $\begin{array}{l}\text { Members have the right of the funds while } \\
\text { insurance company just manage the funds }\end{array}$ & $\begin{array}{l}\text { Insurance company has the } \\
\text { right of the funds }\end{array}$ \\
$\begin{array}{l}\text { The Source of } \\
\text { claim funds }\end{array}$ & $\begin{array}{l}\text { Tabarru'funds } \\
\text { Profit }\end{array}$ & $\begin{array}{l}\text { From the insurance } \\
\text { company's fund account }\end{array}$ \\
& $\begin{array}{l}\text { Profit sharing among companies and } \\
\text { insurance participants according to the } \\
\text { proportion that has been determined. } \\
\text { Risk sharing }\end{array}$ & $\begin{array}{l}\text { All profits belong to the } \\
\text { insurance company }\end{array}$ \\
Concepts & Cash basis & $\begin{array}{l}\text { Risk transfer } \\
\text { Accounting system }\end{array}$
\end{tabular}

Some of previous studies about Islamic insurance described the factors affecting Islamic insurance preference such as Husin and Rahman (2016). Results of this study were individual factors such as awareness, knowledge, and exposure impact on takaful (Islamic insurance) participation. Study by Akhter and Hussain (2012) analyzed about takaful standards and customer perceptions affecting takaful practices. The results of this study showed that the standard of reporting and internal controls had a low level of obedience among insurance operators. A survey on insurance customer revealed that the majority of respondents (91\%) 
were unaware of takaful concept. Moreover, education was found to be a factor affecting the income of respondents, perception, and awareness level of takaful. Other study was conducted by Husin et al. (2016) discussed about the roles of mass media, word of mouth, and subjective norm in family takaful purchase intention. The results of this study concluded that subjective norm, word of mouth, and mass media significantly affected consumers' intention to purchase family takaful.

Studies on takaful around the world were conducted such as by Sherif and Shaairi (2013) that explained the determinants of demand on family takaful in Malaysia. The result of this study showed that income, development of Islamic banking, education, dependency ratio, and Muslim population were positively related to demand for takaful. On the other hand, inflation, real interest rates, financial development, and life expectancy negatively affected the use of family takaful. Other study was conducted by Maturi (2013) described about Islamic insurance in the UK. The study revealed a result of a survey about respondents's tendency to buy insurance for car, health, home, and its property if it has the same transaction form as conventional insurance as well as competitive prices. The study also showed that there was a lack of awareness of takaful and its main principles. Echchabi and Olorogun (2014) described about Islamic Insurance Prospects in Tunisia. Overall, the result showed that customer in Tunisia was willing to use the service. In addition, the ability of Islamic insurance services became a decisive factor of their decision. Al-Amri (2015) explained the takaful insurance efficiency in the GCC Countries. Results of this study indicated that takaful industry in GCC was very efficient in terms of technical and pure technical efficiency. However, it was categorized as "fairly" efficient in term of cost since there were great opportunities for improvement. The highest technical efficiency score was obtained by UAE and Qatar, while Saudi Arabia and the UAE were found to be the most efficient countries in terms of the cost among the GCC countries. Rahman (2009) in his study entitled 'Takaful: Potential Demand and Growth" aimed to describe the potential of demand and growth of takaful worldwide. The result of this study showed that takafulindustry increases each year and is expected to continue to grow by $15 \%-20 \%$.

\section{Method}

This research applied the Analytic Network Process (ANP) approach. This approach is the development of Analytical Hierarcy Process (AHP) method. AHP method is a weighting method often used in designing a performance measurement system (Hidayati, 2012). It is a decision support model developed by Thomas L. 
Saaty. This decision support model is multi-criteria in assessing the priority of criteria and indicator used (Ibrahim et al., 2013).

This study consisted of several stages of ANP modeling grouped into three phases. The first phase was a model construction or decomposition to identify, analyze, and structure the problem complexity in ANP network. In this phase, a literature review was conducted to gather problems associated with the object examined. Later, problem complexity was structured into the ANP framework. Understanding the problem can be done through theoretical basis, literature study, questionnaires, and in-depth interviews. Validating the model to experts and practitioners who were respondents was conducted further.

The second phase was model quantification or pair comparison. In this phase, ANP questionnaire was prepared and a survey of experts and practitioners was performed. Questionnaires were made in accordance with the ANP framework. Then, numerical scale was given. Distribution of questionnaires was carried out separately for each respondent. Filling the questionnaire was done by assigning numerical scale of 1-9 to determine which one of the two that has greater influence (more dominant) and how big the difference as seen from one side. The third phase was the synthesis and analysis result. Data processing and synthesis were done using ANP software namely Super Decisions. After the data was processed using Super Decisions, conclusions, and decisions were made.

\section{Results and Discussions}

\section{Identification of Problems, Solution, and Strategy in the Industry of Islamic Insurance}

The process of identifying problems in this study was performed through literature review, in-depth interview, and focus group discussions (FGD). In the stage of Analytic Network Process (ANP), in-depth interview with experts was conducted to explore problems occurred in Islamic insurance industry. In addition, aspect of solution was also identified to provide answer as well as to design appropriate strategies to solve the problems. Problems were also examined through literature study by exploring journals, scientific papers, and other relevant sources.

Problem in the development of market potential in Islamic insurance was detected in four clusters, namely internal problem of Islamic insurance, problem of customer, problem of competition, and problem of regulation. Explanation of each cluster of problems and solutions is as follows. 


\section{Internal Problem and Solution of Islamic Insurance}

There were four criteria of problem and alternative solution in the cluster of internal problem, namely problem and solution of socialization and product promotion; problem and solution of human resource; problem and solution of technology; and problem and solution of product development.

The important aspects that affect the development of a product are marketing and socialization of the product itself. This is consistent with research conducted by Husin et al. (2016), which showed that the role of mass media or promotion significantly affected consumers' intention to buy family takaful. In addition, marketing is an organizational function and a set of process for creating, communicating, and delivering value to customers and for managing customer relationships in ways that benefit both organization and its stakeholders (Kotler and Keller, 2009). Along with the growth and development of the business world, high competition between companies rises as companies intend to strengthen their position in the market. Market forces will be formed when the marketing and promotion is effectively and efficiently performed.

Result of in-depth interviews with several experts showed that Islamic insurance has not yet maximal in marketing and promoting its products to public. This causes the Islamic insurance market could not rapidly develop as Islamic finance industry with a very large portion. Islamic insurance market is supposed to be in line with the growth of Islamic financial institutions as a whole (FGD, 2017).

Solution concerning the lack of socialization and promotion of Islamic insurance products is the optimization of marketing strategies, both in traditional and modern ways. Traditional marketing strategies such as the creation of pamphlets, brochures, sales marketing, and advertising need to be supported with modern promotional approaches such as online marketing, digital marketing, advertising in the electronic media, television, social media and so on (FGD, 2017). This is also supported by a study conducted by Saputra and Mahalli (2014).

A classic problem in many Islamic financial institutions is the limited Human Resources (HR) both in terms of quality and quantity. HR quality can be seen from the performance of employees. The lack of Islamic business knowledge would make a quite structured weakness of Islamic insurance itself. When HR is able to explain the knowledge of Islamic finance, they will be able to provide excellent service and make a stronger positioning in the market of the national insurance industry. On the other hand, the number of employees in the Islamic insurance company is still minimal. A small quantity of Islamic insurance employees and agents would result in an impact on excellent service provided to customers (FGD, 2017). 
To deal with the problem of limited quality and quantity of human resources, increase in quantity and improvement of quality can be achieved by increasing the number of $\mathrm{HR}$ and capacity improvement through gradual training and coaching in each level. This is consistent with research conducted by Apriandi and Findi (2013) as well as Ascarya and Yumanita (2009). Moreover, recruitment of prospective employees can be applied by cooperating with higher education institutions both public and private, which offer a program of sharia economics, Islamic finance and business, sharia management, Islamic banking, and Islamic accounting. The readiness of employees of higher education institutions can be prepared through a short course or certain professional certifications related to division required (Effendi, 2017). It is supported by a study carried out by Saputra and Mahalli (2014) and FGD (2017).

Industrial development is influenced by the rapid development of information technology. An industry must be able to adapt to the development rate of information technology. Technology can be a serious threat and a huge opportunity. Industrial companies, both that provide goods and services, should be able to take the opportunity concerning the presence of world digitalization that has globally spread. Conventional Customers have changed into modern customers who feel more comfortable to do surfing on the internet and other media. Islamic insurance company is seen to have not yet utilized the existing information technology (Imaby, 2017, Noekman, 2017).

Hopefully, technology can simplify the existing service facilities such as registration, donation deposit, accountancy, risk claim, and its redemption can be performed online to eliminate face to face transaction. Easiness through technology-based transactions is highly anticipated by customers and prostective customers. Solution offered is the optimization of information technology for the expansion of marketing, targeting new insurance customers, performing transactions via online systems, and so on. Islamic insurance is expected to be able to capture the moment of digital world movement with optimal and excellence service. Upgrading the existing system, both in term of management and technology, is an appropriate solution for capturing great potential of national Islamic insurance market. This statement is supported by research conducted by Ichsan (2011); Saputra and Mahalli (2014).

Development and innovation of product is an important aspect in a company. Islamic insurance is a new player in the world of national insurance industry, which began in 1994 with the establishment of PT. Syarikat Takaful Indonesia. Products of Islamic insurance are still considered to be monotonous and less varied. Thus, product innovation and its development are required in order to compete with 
other competitors in the market. Internal personnel of Islamic insurance should make a new breakthrough in the development of products, which later becomes special characteristics of Islamic insurance. Development of product is done by observing consumer and the existing market pattern. Furthermore, aspect of service should also be upgraded considering the fierce competition of insurance industry. Service excellence is one of the key answers to boost the potential of national Islamic insurance market. Most people are still being rationalist/opportunist than being idealist or emotionalist. When conventional insurance service is performed better and more comfortable, people will remain to be loyal as its customers. It is a rationality encouragement (FGD, 2017). Similar statement was also stated by Noekman (2017), and Imaby (2017).

\section{Problem and Solution of Customer}

There were four criteria identified in the aspect of problem and solution of customer included the lack of customer willingness to perform sharia transaction, the lack of understanding of Islamic insurance, rational encouragement, and habit to use conventional insurance and perception of mimicry of conventional insurance products. Explanation of problem and solution of customer will be outlined as follows:

Approximately, $85 \%$ of Indonesian people are Muslims amounted to 240 million people that is a huge potential. However, this number was not in line with the total number obtained by the overall market share of national Islamic financial institution including Islamic insurance. Market share of Islamic insurance in 2015 amounted to $5.98 \%$ of total Islamic insurance industry. This percentage indicates that many Muslim communities in Indonesia have not joined the Islamic finance transactions. Maturi (2013) stated that most of the customers of takaful have lack of willingness of the takaful principles. In addition, Husin and Rahman (2016) described that willingness and knowledge are able to affect more participants to joint takaful.

Many factors are possible to be the reason and one of them is the unwillingness of people to perform sharia transaction. Imaby (2017) stated that the result of an indepth interview showed that society in general know the interest system and usury are forbidden, and also know that the system ensnares a party. The big problem is public awareness to participate in the development of national Islamic finance industry by becoming customer of related industries. Another concern expressed in FGD (2017) is that the unwillingness will remain exist since public think that Islamic insurance is similar to conventional insurance.

Until now, both society and industry players have less knowledge of Islamic insurance. Akhter and Hussain (2012) conducted a research and found that about $91 \%$ of the respondents do not understand about takaful concept. Moreover, Maturi 
(2013) described that most of the respondents of his research know little about the main principles of Islamic insurance. Most of the respondents just concerned about riba and maysir. Some of them believed that the transaction forms are just similar with its counterparts. Today's society as well as several industry players understand that Islamic insurance has the same concept as conventional insurance. The concept of risk sharing that is the characteristic of Islamic insurance is poorly understood by industry players, which cause users or people still think that the concept of Islamic insurance is risk transfer. The existence of risk sharing concept especially if it is socialized properly will show that Islamic insurance industry has advantage compared to conventional insurance (Noekman, 2017).

Motive of people in choosing insurance is still largely driven by rationality. Preference of people in choosing insurance is based on facilities, services and benefits they will get. Several insurance users assume that Islamic insurance does not provide better services compared to conventional insurance. Some of them also think that Islamic insurance does not promise high returns compared to conventional insurance, even users of insurance who already have conventional insurance policy are reluctant to switch to Islamic insurance because they consider that Islamic insurance is not different from conventional insurance (FGD, 2017).

Limited variety of products offered by Islamic insurance and lack of education regarding the different between Islamic insurance and conventional make people assume that Islamic insurance mimics the products of conventional insurance. In fact, some people think that Islamic insurance is the same as conventional insurance and the only difference lies in the label of "sharia" in Islamic/sharia insurance. Therefore, this is a hard work for the industry players in order to educate people properly and to create more varied products that are still within the corridor of sharia (FGD, 2017 and Noekman, 2017).

\section{Problem and Solution of Competition}

Conventional insurance has existed longer than Islamic insurance. It is therefore not surprising that conventional insurance is more widely known by public than Islamic insurance, which had just entered the national insurance market several years ago. Marketing strategy, adequate infrastructure, and professional human resources also support the existence of conventional insurance. Thus, the market penetration of conventional insurance is rapidly growing (FGD, 2017).

The growth of Islamic insurance asset currently is quite well which was about 21.69 percent in 2016 (AASI 2016). However, market share of Islamic insurance is still relatively small compared to conventional insurance. In terms of assets, market share of Islamic insurance only reached 5.63 percent in 2016 (AASI 2016). It is 
a hard work for Islamic insurance to increase its market share since the growth of conventional insurance is supported by adequate infrastructure and human resources.

Pricing of premium or donation in Islamic insurance for some people is still seemed to be less competitive and still-oriented to pricing of conventional insurance. Moreover, concerning the claim, most Islamic insurance may not cover the costs or losses to customer because the type of funds in Islamic insurance is tabarru. Thus, it cannot cover all costs or losses of customers as in most conventional insurance.

\section{Problem and Solution of Regulation}

Some financial institutions and other institutions that issue Islamic/sharia products do not use Islamic insurance as a means of protection. For example, some financing activities in several Islamic banks still use the services of insurance broker. Some brokers may already use Islamic insurance, but some other still use conventional one. Apart from Islamic banking, sukuk as an Islamic product still uses conventional insurance. Similar case is also found in Hajj and Umrah of which most pilgrims still use conventional insurance. Conventional insurance often cooperates with conventional company. Therefore, whenever people register for Hajj and Umrah, they will be directly registered to conventional insurance. Brokers of insurance so far are not supervised by appropriate authority of sharia compliance despite they handle many customers of Islamic banks. Brokers should be given restriction so that they insure the customers of Islamic banks in Islamic insurance. During this time, if customers do not ask for Islamic insurance products, the broker will automatically use conventional insurance.

\section{Aspect of Strategy}

\section{Strategy to improve the quality of service}

Some references from insurance-related journals showed that service provided by insurance companies is the main consideration taken by customers in choosing insurance products, both Islamic and conventional insurance. Moreover, there is also increasing rationality of customers in choosing products and insurance company that can provide excellent service quality and promised benefits. In Tunisia, Echchabi and Olorogun (2014) mentioned that custumers are willing to adopt Islamic insurance service. It becomes the main factor that affects them to choose the Islamic insurance. Therefore, strategy for improving the quality of service for Islamic insurance in order to increase the number of customers is 
necessary. In this case, improvement of quality and quantity of human resources in Islamic insurance is one effort in improving service quality of Islamic insurance (FGD, 2017, Noekman, 2017).

\section{Strategy to improve the relationship and synergy between authorities and Is- lamic financial institution}

Islamic finance industry consists of Islamic banking, Islamic capital markets, Islamic insurance, and other Islamic non-banking financial institutions. Therefore, synergy or cooperation between relevant institutions is necessary so that they will together grow and develop. One example is the cooperation between Islamic banking and Islamic insurance. Regulation that states Islamic finance should use Islamic insurance shows that Islamic products must be performed as a whole. Thus, it cannot be mixed with conventional products (FGD, 2017).

\section{Strategy to socialize Islamic insurance products}

Some journals related to preference for Islamic insurance mentioned that Islamic insurance requires socialization or promotion in order to expand the market. More socialization conducted by industry players is necessary since it is considered inadequate. Besides, education about Islamic insurance products is yet not enough. It can be seen from the lack of public knowledge in Islamic insurance product that applies the principle of risk sharing. Additionally, many people think that Islamic insurance is the same as conventional insurance. Therefore, relevant authorities to increase promotion and at the same time provide education for public in general and insurance clients can also assist Islamic insurance companies in particular (FGD, 2017).

\section{Supporting affirmative policy from the authority and government}

To promote Islamic insurance industry, cooperation in the form of affirmative policy from related government agencies such as the OJK (Otoritas Jasa Keuangan, Financial Service Authority), the Ministry of Finance issuing sukuk, and the Ministry of Religion that facilitates the pilgrimage. This affirmative policy aims to restrict conventional insurance entering the market that should be owned by Islamic insurance, such as Islamic banking, Islamic capital market (including sukuk of government and corporate), as well as insurance for Hajj and Umrah. Currently, regulation on the use of conventional insurance in Islamic finance industry is still considered less binding. 


\section{Conceptual Framework of ANP}

In the description concerning problem that exists in strategy to increase market potential of Islamic insurance, there are four categories obtained, namely internal of Islamic insurance, customer, competition, and regulation. In addition, clusters of problem identification in this study are shown as follows of conceptual framework of Analytic Network Process (See Figure 2).

Figure 2. Conceptual Framework of Research

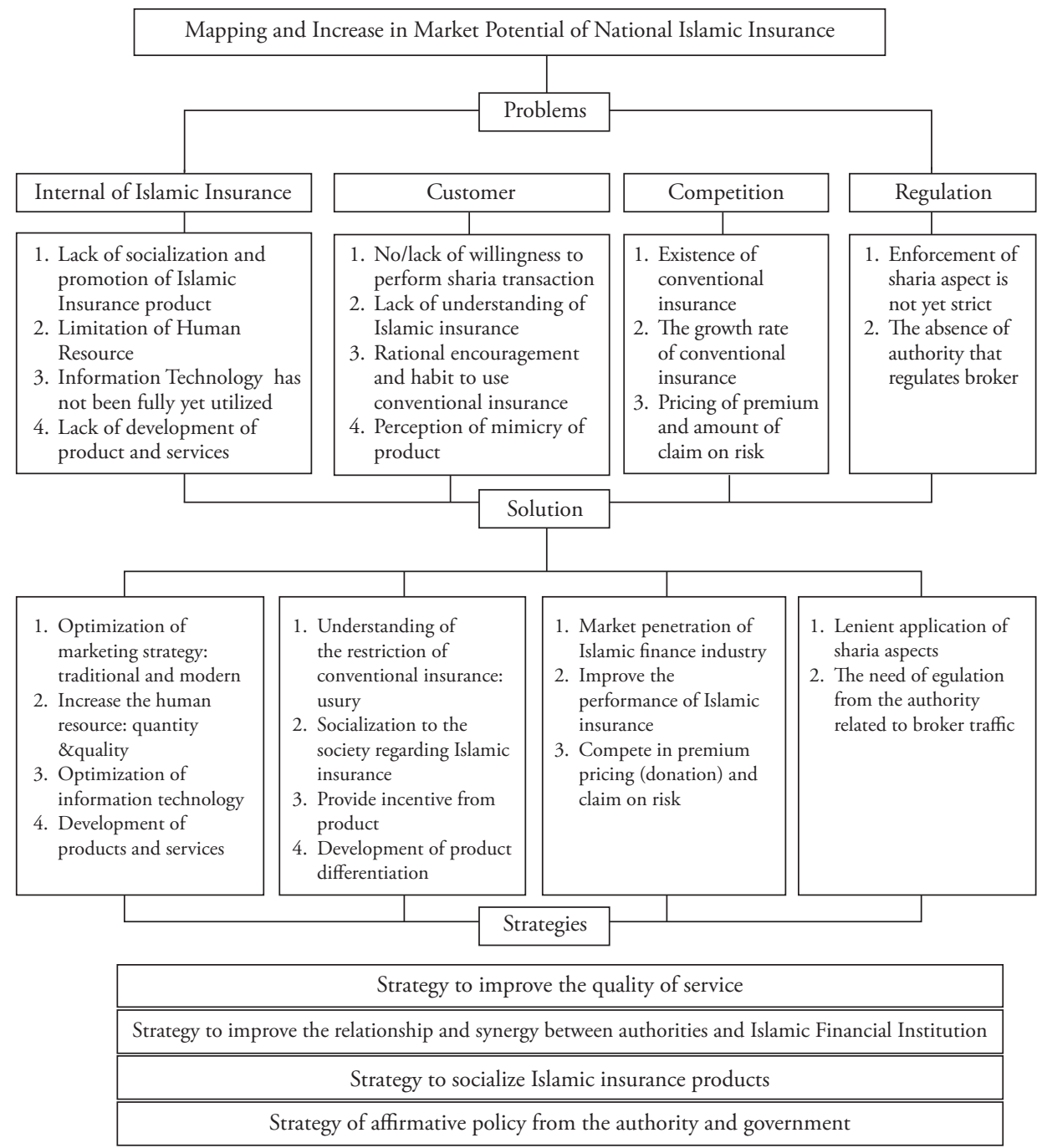


Based on the result of survey on six respondents of experts, questionnaire data collected from those six respondents were then processed according to the result of questionnaire of each respondent by considering the framework of ANP. In this stage, overall results obtained from respondents' opinion would be discussed and the results of problems, solutions, and strategies would also be explained according to respondents by considering Geometric Mean to observe priorities and Rater Agreement (W), which shows the agreement of respondents in an effort to increase the potential market of Islamic insurance.

\section{Result of Rater Agreement of Cluster of Problem}

Figure 3 shows that respondents of experts see that the lack of socialization and promotion of Islamic insurance products to public $(0.28)$ is the first priority of existing problem in efforts to increase potential market of Islamic insurance, which is followed by limitations of human resources both in quality and quantity (0.26). The third priority is the lack of development of products and services $(0.24)$ and the last is the lack of utilization of information technology at maximum (0.20).

This study places lack of human research as a second priority, but most of the researches stated that limitation of human resources is the main problem for most of Islamic financial institutions such as researches conducted by Rusydiana and Devi (2013), Apriandi and Findi (2013), as well as Ascarya and Yumanita (2005). However, study by Husin et al (2016) is consistent with this research.

Figure 3 Result of Rater Agreement of Intenal Problem

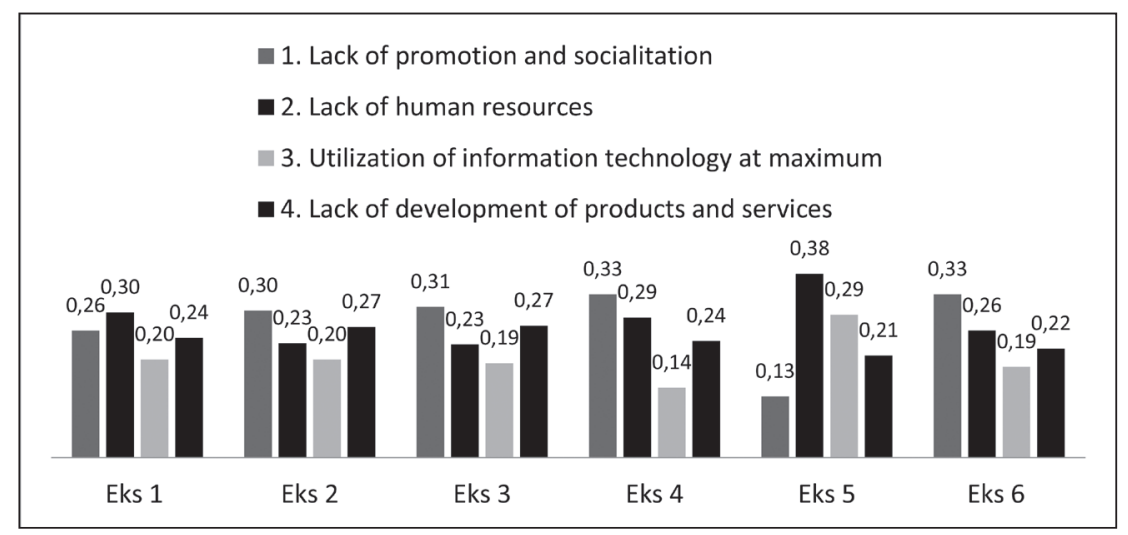

The next problem is the problem of customer, which consisted of four criteria. According to the processing result in Figure 4; from six respondents of experts, a 
thread priority is able to be pulled, which starts with the first priority that is the lack of understanding of Islamic insurance both conceptually and operationally (0.31). The next is the rational encouragement and habit in applying conventional insurance transactions (0.25). The third level in priority of problem of customer is the lack of willingness to perform sharia transaction (0.23) and followed by perception of mimicry of conventional insurance products (0.19). The lack of public understanding is considered as priority problem within the customer. It is surely will be a priority to increase the market potential by solving the problems of lack of public understanding concerning Islamic insurance. This result is similar with studies concted by Akhter and Hussain (2012) as well as Maturi (2013) that mentioned most of respondents of their research have lack understanding of Islamic insurance.

Figure 4 Result of Rater Agreement of Customer's Problem

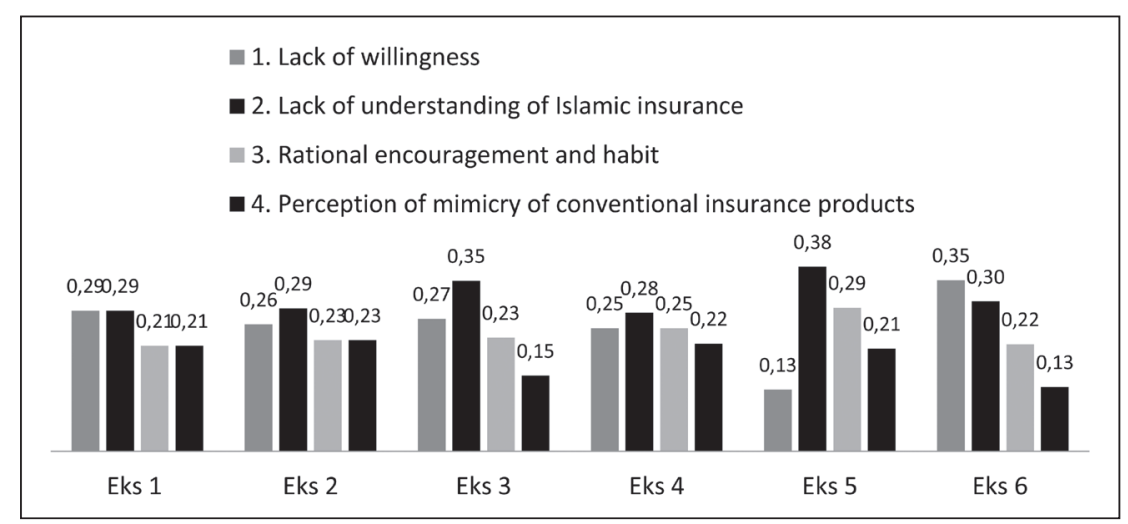

In term of criteria of competition's problem, there are three aspects obtained. Result of data processing from these criteria was dominated by the long existence of conventional market (0.35). This condition illustrates that competition faced by Islamic insurance in national insurance industry is extremely hard as Islamic insurance started to develop in 1993-1994, while conventional insurance has already established for a long time. Thus, market is mostly dominated by conventional insurance. The next priority is the growth rate of conventional insurance. This is certainly driven by the long existence of conventional insurance industry that the growth rate is still quite high (0.33). The last priority is the competition in premium pricing and the amount of claim on risks conferred by the opponent industry $(0.30)$. Considering the three values that have almost the same level of interest with range of 30 percent, it means that the three problem identifications are equally strong in term of industrial competition. (See Figure 5). 
Figure 5. Result of Rater Agreement of Competition's Problem

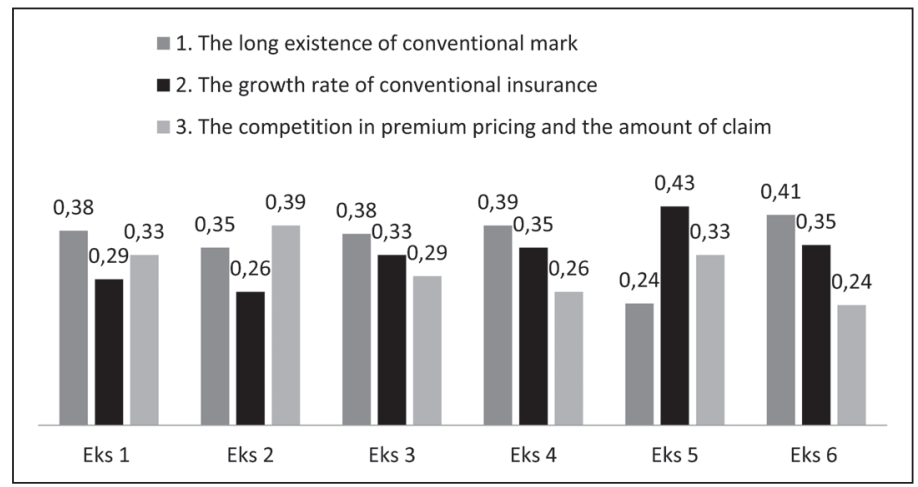

At the stage of identification of regulation's problem, there are only two criteria namely the lenient enforcement of sharia aspects in national Islamic insurance industry and the absence of authority that legally regulates brokers in the market. All respondents agreed that the main priority is the implementation of sharia aspects enforcement which is not yet strict $(0.53)$ percent and the broker regulation problems ( 0.47$)$. So far, Islamic banks and other Islamic financial institutions still use the services of brokers of which their position have not yet been fully regulated in the aspects of sharia. This leakage can reduce the potential of Islamic insurance market. (See Figure 6).

Figure 6 Result of Rater Agreement of Regulation's Problem

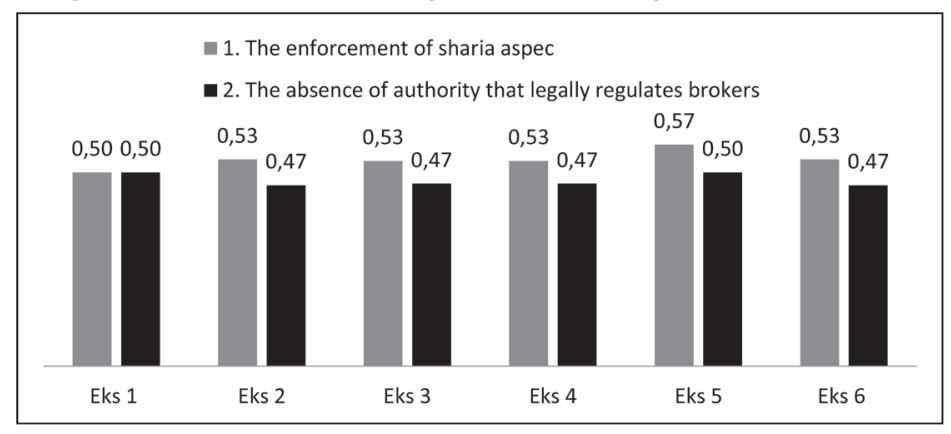

Figure 7 describes that there are many different patterns appeared between respondents of practitioners and respondents of academics. Expert 3, 4, 5 and 6 are expert of practitioners who consider that regulations or rules of insurance industry is the principal problem in the development of Islamic insurance market, while practitioners considered that intenal aspect is the main priority. However, value of limiting priorities indicated that both of them achieved the same value of 0.28 of each and followed by problem of customer and competition of 0.21 and 0.19 percent, respectively. 
Figure 7. Result of Rater Agreement of Cluster of Overall Problem

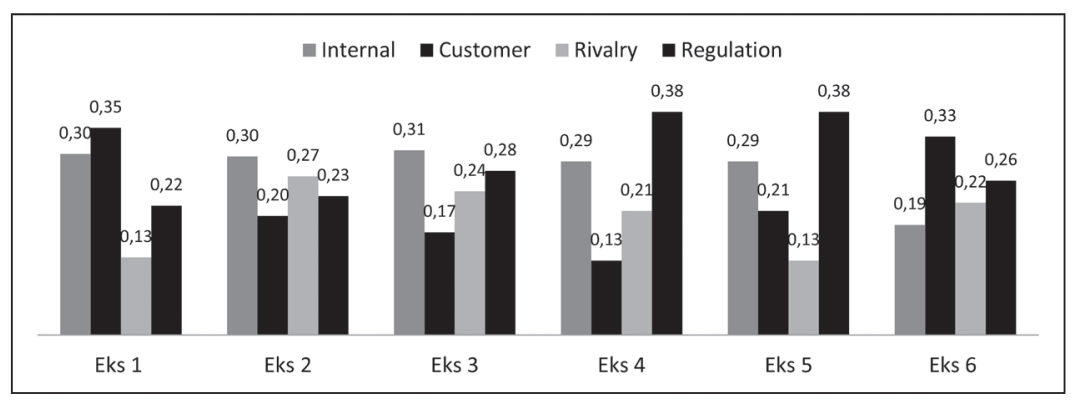

\section{Result of Rater Agreement of Cluster of Solution}

In the aspect of intenal solution in Islamic insurance (Figure 8), experts stated that the main solution is the development of product $(0.28)$, followed by optimization of marketing strategy $(0.25)$. These two things became the core priority to boost the potential of the existing insurance market. The development of more innovative products and good marketing strategies with traditional and modern models is considered capable and be a pressing point of problem solving for internal of Islamic insurance. The third priority is the optimization of information technology in various transactions (0.23). This result was because technological developments can be a massive crawler of market as the presence of customer pattern shift now. At last, improvement of human resources can be done through in both quantity and quality through training, coaching, and assignment (0.22).

Figure 8. Result of Rater Agreement OF Solution of Internal

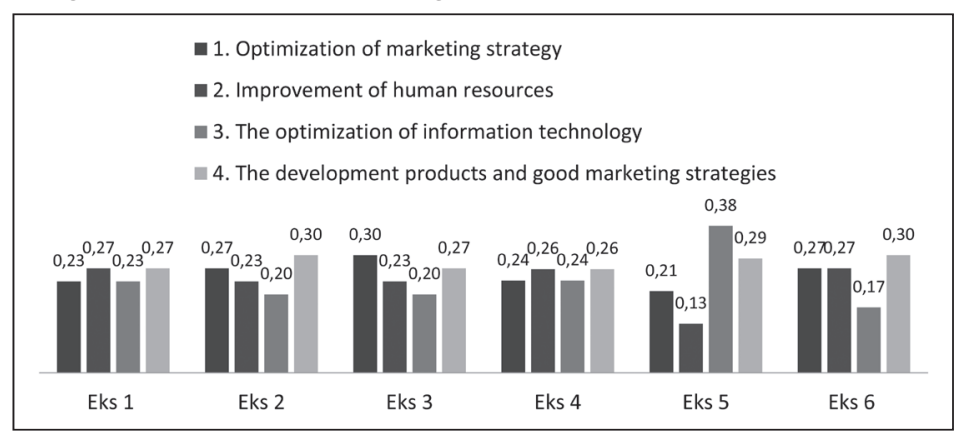

In the aspect of solution of customers, result of data processing from experts as seen in Figure 9 shows that sosialisation of products to public is considered very important and is the focus of priorities in the solution of customer (0.29), followed by the development of Islamic insurance product differentiation (0.24). Product 
that has a specific and particular characteristic can attract customers. The third and fourth priority is the understanding of restriction to use conventional insurance concerning transaction of usury, gharar and maysir which achieved (0.23), as well as aspect of incentive given for Islamic insurance products (0.23).

Figure 9. Result of Rater Agreement of Customer's Solution

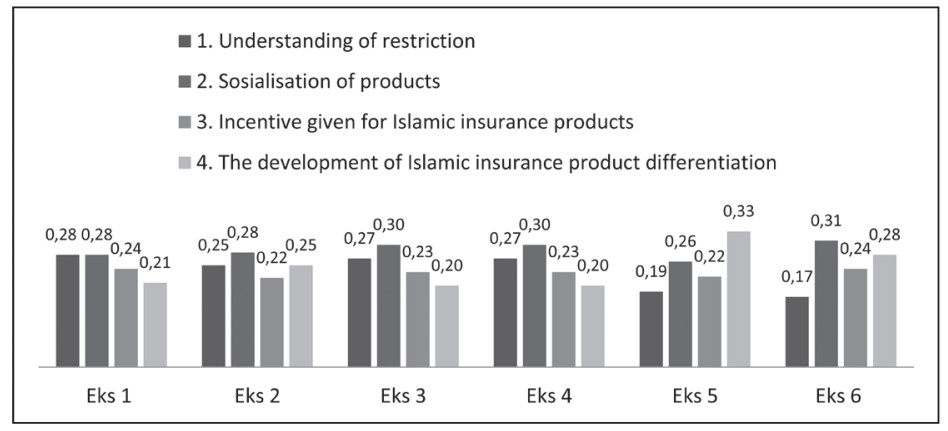

Solution of competition offered in this study contained three criteria with the main priority is to improve the performance of Islamic insurance with value of limiting varieties (0.37). Experts believed that good performance will result in good impact to survive in a competition. Strong performance is the basis to deal with conflicts of national industrial market. The second priority obtained (0.34) for industrial market penetration of Islamic financial institution industry, which was followed by competition in premium pricing and mostly in coverage of risk dependents provided to customers (0.28). (See Figure 10).

Figure 10. Result of Rater Agreement of Competition's Solution

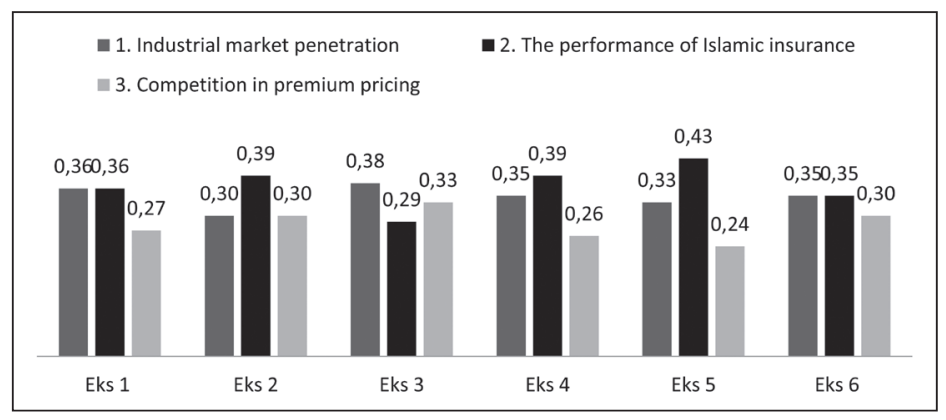

Criteria of solution of regulation occupied the first priority by strict application of sharia aspects operationally as well as the flow of insurance dependents with the amount of insurance dependents (0.52). Respondents in 
this study considered that the position and the appointment of Islamic insurance have not been fully carried particularly when overcome the underlying for sukuk insurance. The second priority is the need for regulator or authority to cover the broker traffic flow in the national insurance industry (0.48). (See Figure 11).

Figure 11. Result of Rater Agreement of Regulation's Solution

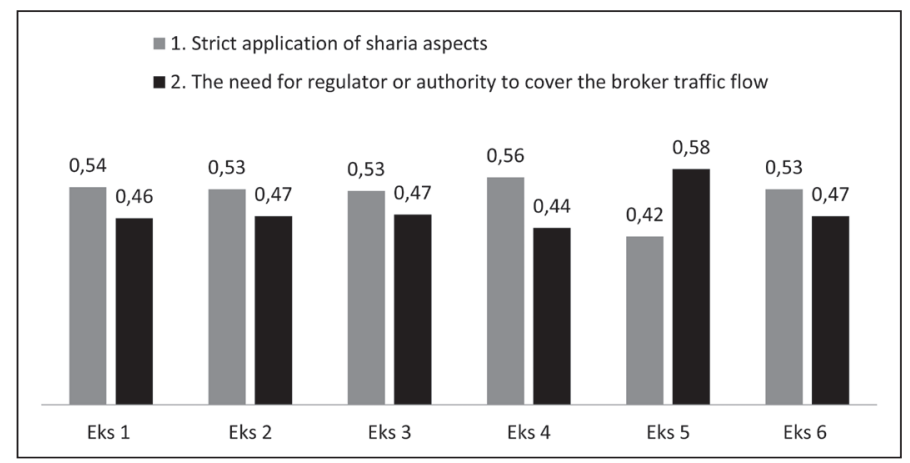

Figure 12 shows that the solution to be the main priority is solution of internal of Islamic insurance (0.30). It is followed by two criteria with the same value namely solution of regulation and solution of customer (0.24). Problems of regulation and customer are considered essential to be resolved and addressed. Practitioners will be more comfortable playing with regulations that will encourage the growth and development of Islamic insurance. The last priority was competition, which is considered less to be the focus of problem because it can be resolved when the internal of Islamic insurance has been secured.

Figure 12. Result of Rater Agreement of Cluster of Solution

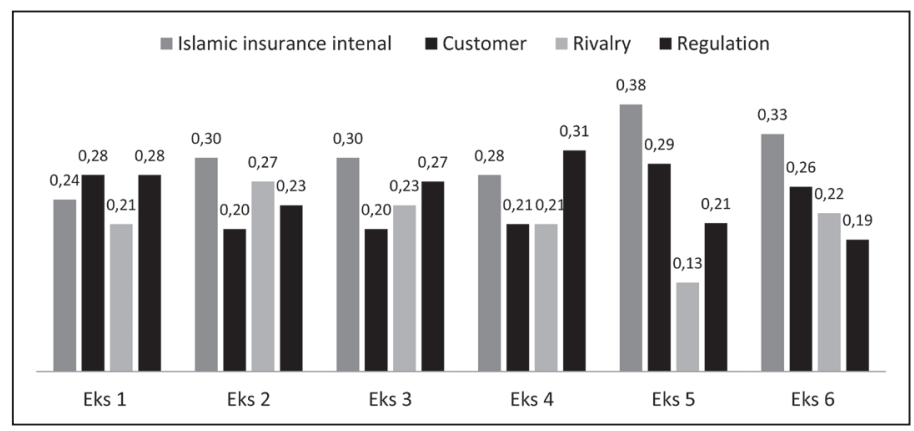

Figure 13 shows various strategies offered by the experts. All experts believe that the strategy of improving service quality is able to push the rate of development 
and to boost the market potential of Islamic insurance today. Quality of service becomes a full reflection in any industry, higher service quality result in increased customer and market, vice versa $(0.29)$. It is followed by the strategy to socialize products $(0.27)$ the improvement of relationship and synergy of Islamic financial institutions as a whole (0.25). The last priority given rate by the respondents of expert was affirmative policy that supports sharia industry from the authority and government (0.18). This finding shows that there is still lack of regulation that supports the development of Islamic insurance market.

Figure 13. Result of Rater Agreement of Cluster of Strategy

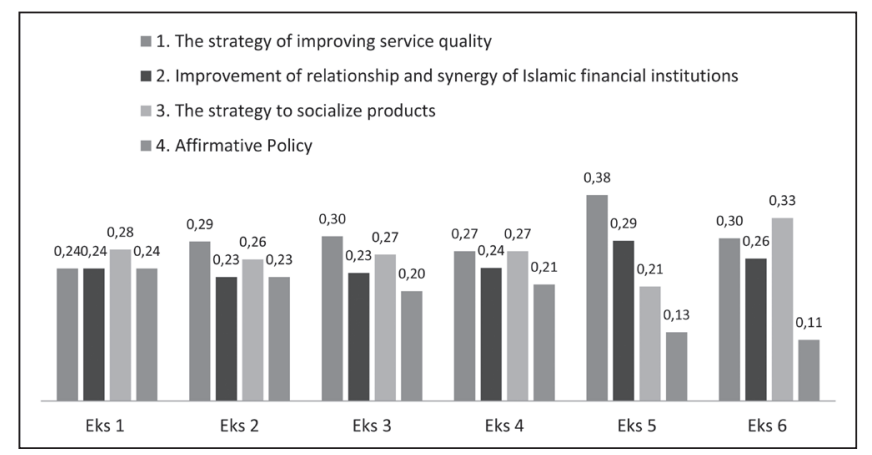

\section{Result of Geometric Mean of Problem}

Discussion of geometric mean indicates the level of priority that is considered the most significant to apply to increase the market potential of Islamic insurance by respondents of experts in this study. Geometric mean intends to examine the trend in all respondents when regard the problem.

Figure 14. Result of Geometric Mean of Problem

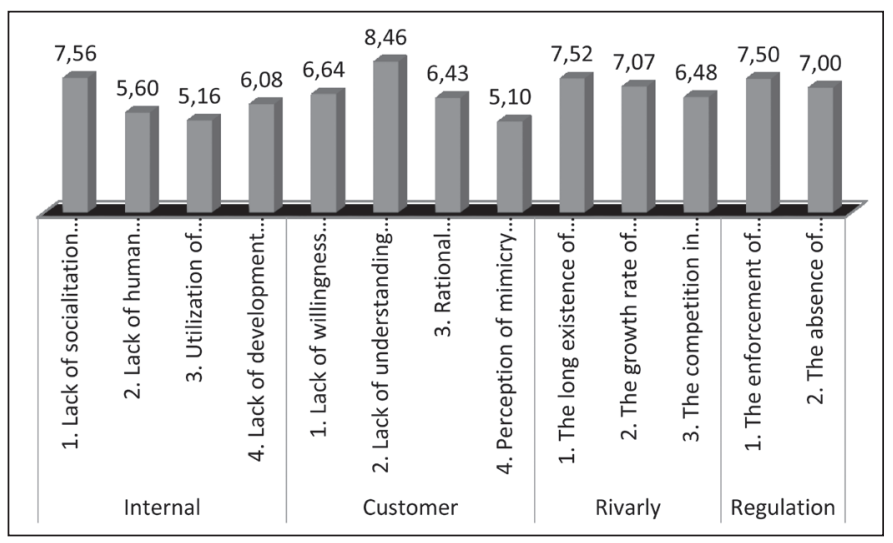


Figure 14 shows that the biggest problem of internal was occupied by the lack of socialization conducted by Islamic insurance to public (7.56), followed by the lack of development of products and services (6.08). These two problems are believed to be the key problems, which exist all the time in Islamic insurance. Socialization and innovative level that are not maximal become problems that should be solved well. The last is the limitation of human resources and utilization of information technology that is not maximal with results of 5.6 and 5.16, respectively.

Customer's problem considered the most dominant is the lack of understanding of Islamic insurance both operationally and conceptually. It results in less willingness in performing sharia transaction. Furthermore, in terms of competition, the existence and strong conventional insurance industry were found to hamper the development of Islamic insurance market. In addition, strengthening the aspects of sharia in field implementation with a value of 7.50 can solve problem of regulation.

Figure 15. Result of Geometric Mean of Solution

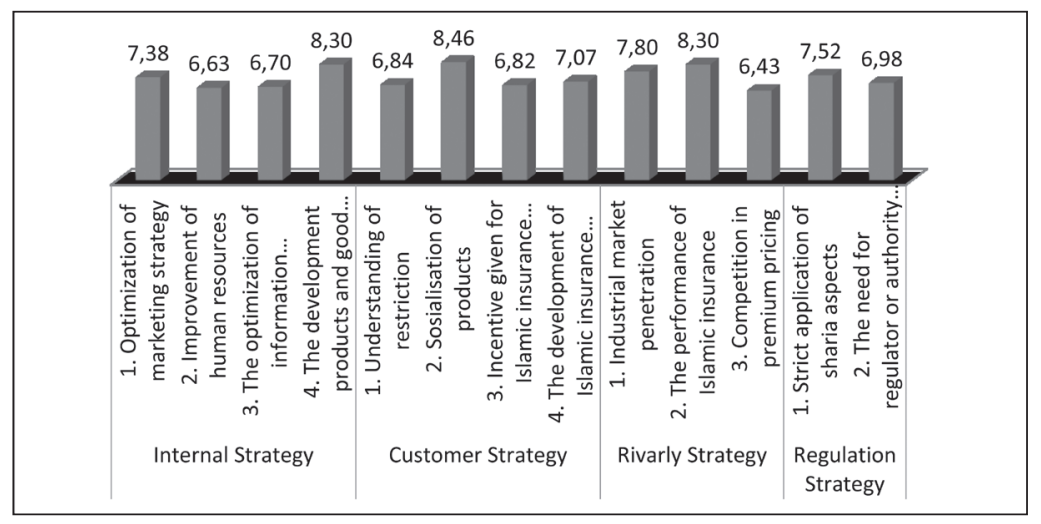

\section{Result of Geometric Mean of Solution}

In the aspect of solution, geometric mean, which shows the tendency of all respondents of experts on solution of internal is the development of Islamic insurance products with a value of 8.30 and was followed by solution of customer through socialization with a value of 8.46 in criteria of solution of internal, product development is considered as the key solution to develop good industrial foundation and maximum socialization to the community, which can be a solution of customer's problem.

Concerning the solution of competition, respondents thought that improvement of performance is able to strengthen the position in the existing 
industry competition with geometric mean value of 8.30 , while solution of regulation is still occupied by strict application of sharia aspects as seen in the value of rater agreement in Figure 15.

\section{Result of Geometric Mean of Strategy}

Considering the result of strategy, improvement of service quality obtained the first priority with a value of 8.46 and followed by socialization of product, which reached a value of 7.69. Two strategies are considered the most appropriate to increase the potential of national Islamic insurance market. Excellent service and intensive socialization will certainly have impact on market increase both from customers and competition. On the other hand, improvement in relationship and synergy between the authorities and Islamic financial institution also considered to be increased without denying that the existing regulations are able to facilitate and promote the development of national Islamic insurance industry (See Figure 16).

Figure 16. Result of Geometric Mean of Strategy

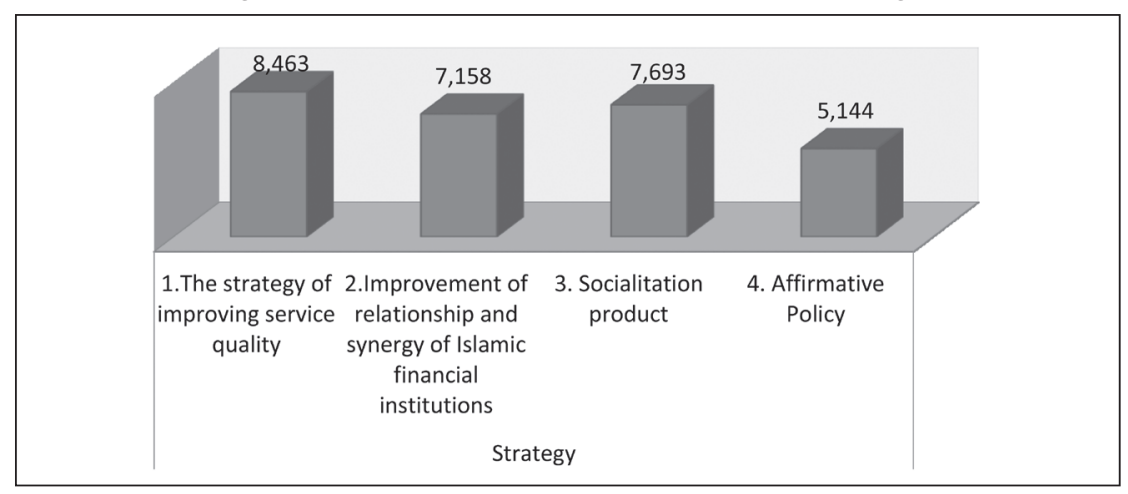

\section{Conclusion}

In efforts to increase the potential of Islamic insurance market, this study applied ANP approach by classifying it into three aspects, namely aspect of problem, solution, and strategy. Aspect of problem and solution consist of four clusters including problem and solution of internal of Islamic insurance, problem and solution of customer, problem and solution of competition, also problem and solution of regulation, while strategies offered are strategies to improve the quality of service, strategy to improve the relationship and synergy between the authorities and the Islamic Financial Institutions, as well as strategy of affirmative policy that supports the development of Islamic insurance by the authorities and government. 
Results of data processing from six experts indicate that the predominant cluster of problem of internal to be resolved is the lack of socialization. Moreover, in term of customer's problem, it is the lack of understanding of customer on Islamic insurance.

The last, the existence of conventional insurance industry is problem considered the main problem in the cluster of competition. Cluster of regulation has priorities on enforcement of aspects of sharia in Islamic finance industry. On the other hand, the priority of solution is prioritized in cluster of solution of internal with criteria of product development and service and criteria of marketing optimization through traditional and modern media. Finally, strategy believed to be able to increase the market potential of Islamic insurance is the strategy to improve service quality, followed by the strategy of socialization of Islamic insurance products.

\section{References}

Akhter, W., \& T. Hussain. (2012). Takaful Standards and Customer Perceptions Affecting Takaful Practices in Pakistan: A Survey. International Journal of Islamic and Middle Eastern Finance and Management. 5 (3): 229-240. doi: 10.1108/17538391211255214.

Al-Amri, K. (2015). Takaful Insurance Efficiency in the GCC Countries. Humanomics. 31(3): 344-353. doi: 10.1108/H-05-2014-0039.

Apriandi, F., \& M. Findi. (2013). Solusi Peningkatan Sumberdaya Manusia Pada Baytul Maal wat Tamwil (BMT) di Indonesia Melalui Pendekatan Analytic Network Process (Human Resource Improvement Solutions At Baytul Maal wat Tamwil (BMT) in Indonesia Through Analytic Network Process Approach). Jurnal al-Muzara'ah. 1(2): 107-118.

Ascarya., \& D. Yumanita. (2005). Mencari Solusi Rendahnya Pembiayaan Bagi Hasil di Perbankan Syariah Indonesia (Seeking the Solution for the Low Profit-Sharing Financing in Indonesian Islamic Banking). Buletin Ekonomi Moneter dan Perbankan. 8 (1): 7-43.

Ascarya. (2013). Solutions to Prevent Financial Crisis in Islamic Economic Perspective: ANP Approach. Proceedings of the International Symposium on the Analytic Hierarchy Process.

Asosisasi Asuransi Syariah Indonesia [AASI]. (2015). Peluang, Tantangan Dan Harapan Industri Asuransi Syariah Dalam Perekonomian Nasional dan Global Tahun 2016 (Opportunities, Challenges and Expectations of Sharia Insurance Industry in National and Global Economy 2016). Jakarta: AASI. 
Echchabi, \& L.A. Olorogun. (2014). Islamic Insurance Prospects in Tunisia in The Wake of the Jasmine Revolution A survey from Customers' Perspective. Journal of Islamic Accounting and Business Research. 5 (1): 15-28.

Husin, M.M. \& A.A. Rahman. (2016). Do Muslims Intend to Participate in Islamic Insurance? Analysis from Theory of Planned Behavior. Journal of Islamic Accounting and Business Research. 7 (1): $42-58$.

Rusydiana, A.S. \& A. Devi. (2013). Challenges in Developing Baitul Maal Wat Tamwiil (BMT) in Indonesia Using Analytic Network Process (ANP). Business and Management Quarterly Review 4(2): 51-62.

Husin, M.M., N. Ismail., \& A.A. Rahman. (2016). The Roles of Mass Media, Word of Mouth and Subjective Norm in Family Takaful Purchase Intention. Journal of Islamic Marketing. 7 (1): 42-58.

Kotler, P., \& K.L. Keller. (2009). Manajemen Pemasaran (Marketing Management). Jilid I. Edisi ke 13. Jakarta: Erlangga.

Maturi, T.C. (2013). Islamic insurance (takaful): Demand and Supply in the UK. International Journal of Islamic and Middle Eastern Finance and Management. 6 (2): 87-10.

Rahman, A.R. (2009). Takaful: Potential Demand and Growth. J.KAU: Islamic Econ. 22 (1): 171-188.

Saputra, R., \& K. Mahalli. (2014). Analisis Potensi dan Kendala Pengembangan Pegadaian Syariah di Kota Medan (The Analysis of Potential and Constraints of Islamic Pawnshop Development in Medan). Jurnal Ekonomi dan Keuangan. 2 (4): 221-235.

Soemitra, A. (2014). Bank \& Lembaga Keuangan Syariah (Islamic Bank and Financial Institution). Jakarta: Kencana Prenadamedia Group.

Sherif, M., \& N.A. Shaairi (2013). Determinants of Demand on Family Takaful in Malaysia. Journal of Islamic Accounting and Business Research. 4 (1): 26-50

Swartz, N.P. \& P. Coetzer. (2010). Takaful: An Islamic Insurance Instrument. Journal of Development and Agricultural Economics. 2(10): 333-339.

Quezada, L.E., P.I. Palominos., R.E. Galleguillos., \& A.H. Olmedo. (2014). A method for generating strategy maps using ANP. Journal of Manufacturing Technology Management. 25 (8): 1090 - 1104. doi: 10.1108/JMTM-062014-0081.

Yusuf, R.Y.M. (2011). Revisiting and Redefining The Concept Of Retakaful And The Viability Of Its Model In Malaysian Takaful Industry. Business \& Management Quarterly Review. 2(4): 20-32. 